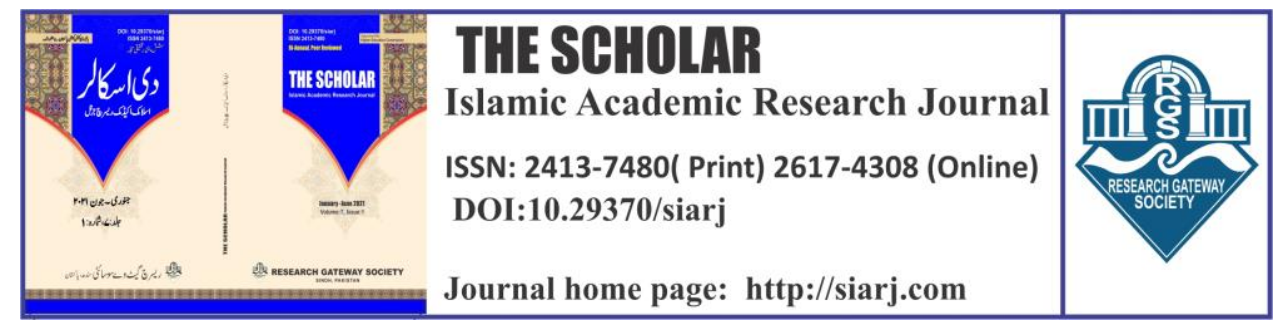

\title{
RELIGIOUS TOLERANCE - A TOOL FOR INTERFAITH HARMONY IN PAKISTAN
}

\section{Imtiaz Ahmad}

Assistant Professor, Department of Islamic Studies, University of Okara, Okara, Pakistan

Email: imtiazahmed010@gmail.com ORCID ID: https://orcid.org/0000-0003-4059-2840

\section{Hafiz Ghulam Abbas}

Assistant Professor, Department of Law Bahria University, Islamabad, Pakistan.

Email:a.ghazi22@gmail.com ORCID ID: https://orcid.org/0000-0003-2430-5039

\section{A Khuhro Muhammad Sajjad}

PhD Law Scholar, Ahmad Ibrahim Kulliyah of Laws International Islamic University, Malaysia

Email: elsonbright@gmail.com

ORCIID IID: https://orcid.org/0000-0001-8317-8645

To cite this article:

Abbas, Hafiz Ghulam Abbas, Imtiaz Ahmad Ahmad, and Muhammad Sajjad Sajjad. "RELIGIOUS TOLERANCE - A TOOL FOR INTERFAITH HARMONY IN PAKISTAN." The Scholar-Islamic Academic Research Journal 7, no. 1 (July 10, 2021). 52-79.

To link to this article: https://doi.org/10.29370/siarj/issue12ar4

Journal

Publisher

DOI:

URL:

License:

Journal homepage

Published online:
The Scholar Islamic Academic Research Journal Vol. 7, No. 1 ||January-June 2021 || P.52- 79 Research Gateway Society 10.29370/siarj/issue12ar4 https://doi.org/10.29370/siarj/issue12ar4 Copyright c 2017 NC-SA 4.0 www.siarj.com 2021-06-30
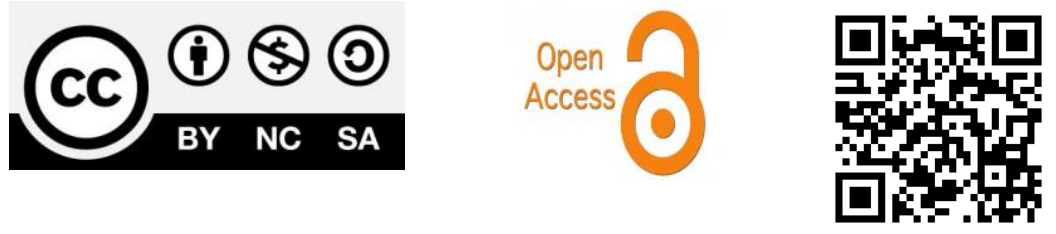
THE SCHOLAR (January - June 2021)

\title{
RELIGIOUS TOLERANCE - A TOOL FOR INTERFAITH HARMONY IN PAKISTAN
}

Imtiaz Ahmad, Hafiz Ghulam Abbas, Muhammad Sajjad

\begin{abstract}
:
Pakistan provides home to people from diverse cultural, ethnic and religious backgrounds. Such variation has become responsible for misunderstandings and conflicts among different groups be it sectarian violence among Muslims throughout country, the language riots, or the continuous violence against non-Muslims. Most of the violence among religious communities is caused by misconceptions about other faiths. Unfortunately, Pakistan has become the victim of such social evils. Pakistan has to take some serious long term steps to eradicate this issue. It is duty upon her citizens and the state to create the environment of harmony and tolerance. In today's modern world where distances mean nothing to us, we can promote peace and harmony in the light of Quran and other divine books. We can also promote positive behaviors and curb ill behaviors such as anxiety, extremism, angriness and violence. This paper aims to achieve the objective of promoting interfaith harmony, peaceful co-existence and acceptance among people belonging to different faiths in Pakistan and alike countries. For conduct of research doctrinal method has been employed with analytical approach.
\end{abstract}

KEYWORDS: Religious tolerance, Interfaith harmony, Minorities, Quran, Other Divine books, Pakistan. 
THE SCHOLAR (January - June 2021)

\section{INTRODUCTION:}

Pakistan is a state of multi-religion and cannot afford any discrimination, misbalance and neglecting attitudes to its religious minorities. Its minorities have their own multi-faceted importance. Several worldwide steps taken recently, have bound the religious leaders to seek some new methods and tools to help "Inter-Faith Harmony". The terrorist-attacks and certain other inhuman activities all over the world, especially Pakistan, have shaken their public at large. Similarly there are some notable challenges to "Inter-Faith Harmony" in Pakistan due to the dearth of collective common sense, religious misunderstandings, biased social behaviors, unfair allocation of socio-economic funds, and misuse of Blasphemy laws. It is requirement of the time to cope with the groups of all religions fairly and equally. Thus, the action should be acceptable by all the groups that the "Inter-Faith Harmony" will cope with the religious issues of the public positively and will transmit a collective, moral and monetary revolution in the country. Under this backdrop, it is essential for the followers of all faiths to enforce the tool of tolerance, peace, patience and "Inter-Faith Harmony". Exceptional beauty of the concept of interfaith harmony and tolerance can be glorified in the light of the teachings of Quran and all other Divine Books by respecting the core and teachings of all religions. This article endeavors to narrate how teachings of Quran and all other Divine Books can be instrumental in achieving the goals of interfaith harmony and tolerance, help eliminate religious extremism and religious bigotry and flourish peace, love and positivity. For conduct of research doctrinal method has been employed with analytical approach.

MEANING OF RELIGION:

\section{LITERAL MEANING:}

Dictionary defines word "Religion" as method, way, belief, opinion etc. 
and religion is the noun adverb, dhahab, yazhab, dhaban, which is used as a source of religion. "The word "Religion" is derived from the French word Religion and Latin word Religio whose meaning is belief, way of worship and being associated with the fear and might of supernatural. ${ }^{2}$

\section{TECHNICAL MEANING:}

Broadened concept of religion has led the men of erudition to define it in exuberant way, which further makes one realize its colossal need and importance. Professor Ghulam Rasool in "Comparative Study of Religions" define religion with reference to Bronite Pede: "Religion is such power of belief which has the force to revolutionize humans and human character provided it is embraced with purity and comprehended with intellect". ${ }^{3}$ Sir E.B. Tailor defines Religion in following words:

"The belief in spiritual being", which means one's belief on having the presence of spiritual realm and having invincible faith on their presence". 4 Aforementioned definitions narrate clearly that the preliminary concept of human beings was religion and monotheistic oriented and this has been explained by Schmidt in following words:

"The basic conceptual framework of human beings was religion oriented and the conception regarding sovereign being was one of oneness oriented which augured the very concept of faith and submission on and before

1 Muhmmad bin Manzoor Alafriqi, Lisan-ul-Arab (Beirut: Dar sadir, 2005), 1/393.

2 Ronald L. Johnstone, Religion in Society: A Sociology of Religion (8th Edn) (New Jersey: Prentice Hall, 2015), 13-20.

${ }^{3}$ Professor Ghulam Rasool, Mzahab-e-Alam ka Tqabli Motalah (Lahore: Ilmi Kutab Khana, 1983), 47.

${ }^{4}$ Encyclopedia of Britannica, the Sixth Editn (Edinburgh: Printed for Archibald Constable and Company, London, 1823), 103. 
Omniscient". 5

\section{THE CONCEPT AND MEANING OF RELIGION FROM ISLAMIC PERSPECTIVE:}

Holy Quran defines "Religion" in this way:

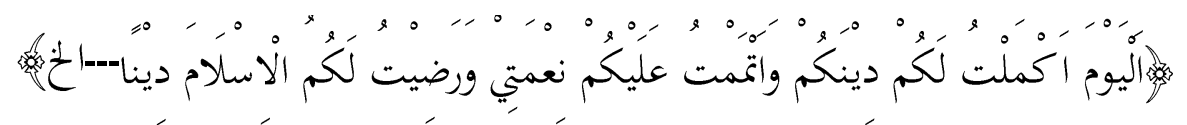

"This day have I perfected your religion for you completed my favor upon you and have chosen for you Islam as your religion....

Religion means all the divine and cosmic religions whose underpinnings are the divine revelations, which means all the religions are unified and coherent with regards to rudimentary concepts. Allah Almighty states:

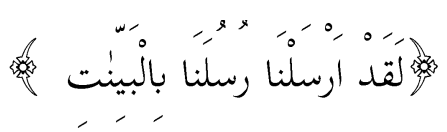

"We sent aforetime our apostles with Clear Signs...",

Forthcoming verses of Holy Quran discern that Noah, Abraham, and rest of Prophets descended with one goal and all the reveled Holy Books have the same message, which is to comprehend the message of Divinity and have strong faith on His Oneness. Islam defines Religion as "Way of life or Code of life" which has been elaborated by Maulana Abu ala Maudodi in following words:

"Religion means a complete way of life as per Holy Quran wherein human as vicegerent submit to a sovereign and obey His commandments with

${ }^{5}$ Wilhelm Schmidt, the Origin and Growth of Religion (Methuen: 1935), 27.

${ }^{6}$ Al-Qurān 5:3. The translation of Quran by Abdullah Yusuf Ali has been followed throughout this paper for the translation of Quranic verses which is available on https://quranyusufali.com/3/

${ }^{7}$ Al-Qurān 57:25 
complete devotion, live a life as per His divine laws and limitations ordained by Him, expect reward and success by obeying His orders and remain scared of humiliation and punitive consequences by disobeying Him. There is not a single comprehensive terminology in any other language like this which could encompass and provide such an allinclusive system of life". 8

\section{MEANING AND CONCEPT OF INTERFAITH HARMONY:}

"Harmony" word connotes "same weight", "appropriateness", "same rank" etc. Syed Ahmed Dehlvi narrates the word "Harmony" in Farhange-Aasfia (Aasfia Dictionary) as:

"Harmonious characteristics", "same vocals", "same opinion", "same symphony", “companion” etc. ${ }^{9}$ Dr. Syed Ali Raza Naqvi writes:

"Harmony means clubbing two or more persons/things in a unified, systematic and coherent way". 10

Harmony connotes "association", "partnership", "companionship", "same rank" etc. ${ }^{11}$ In Arabic Language "Harmony" is synonymous to solidarity, proximity, unification etc. Hence, interfaith harmony means that all the cosmic and divine religions are intrinsically same. The similarities are in the laws of equality, fraternity and justice. All the laws and regulations of the religions are same. The speech of Hazrat Jafar Tayyar (RA) makes it more clear where He recited the verses of Surah Maryam in the court of

${ }^{8}$ Molana Mododi, Quran ki Char Bunyadi Istlahain (Lahore: Islamic Publishers (private) Limited), 132.

9 Syed Ahmad Dahlavi Frhang e Aasfiah (Lahore: Maktbah Hassan Sohail, Limited, 1974) ,4/726.

10 Dr Syed Ali Raza Naqvi, Farhang(Jamae) (Islamabad: National Book Foundation, 1994), 1181.

${ }^{11}$ Waris Sarhindi, Ilmi Urdu Lughat(Lahore: Ilmi kutab khana, 1983), 1591. 
Religious Tolerance - A Tool for Interfaith Harmony in Pakistan

King Najashi, and whose veracity and truthfulness was acknowledged by the courtiers and King Najashi Himself. ${ }^{12}$ Undoubtedly, teachings of all the religions are same though it have become an uphill task to unify all divine religions but effort can be made to bring all the people closer belonging to different faith by promoting the basic concepts of equity, equality, respect, peace, love and brotherhood.

\section{NEED AND IMPORTANCE OF INTERFAITH HARMONY: IN THE DEVINE SCRIPTURES PERSPECTIVES:}

After realizing the nature of basic commandment and similarities preached and conveyed by first Prophet Hazrat Adam and the last Prophet Muhammad, it comes to fore that all religions convey the same message of universal brotherhood, peace and love and this very essence eliminates the contradiction, anarchy and chaos among all the Divine faiths and people same to appear in similar and equal ranks. This is the fundamental premise of all the faiths, which paves way for human success and ultimate goal of peace, and which will not be materialize until humans do not respect one another's faith.

\section{RESPECT OF FAITHS AS PER HOLY QURAN:}

Reverence of narrative, opinion, stance, thinking, argument, reason and logic greatly helps in avoiding bloodshed, anarchy, atrocities, barbarism etc. In the light of these principles of Islam, no only gave huge respect to the people of other faiths but cooperated with them socially, politically and economically to unravel the solutions of contemporaneous complexities. This is one of the cardinal principles of Holy Quran:

\footnotetext{
${ }^{12}$ Muhammad Hussein Heickl, Hayyat-e-Muhammad (PBUH), trans. Abu Yahya Imam Khan (Lahore: Ilm-o-Irfan publishers, 1999), 200.
} 
Religious Tolerance - A Tool for Interfaith Harmony in Pakistan

眾

"Let there be no compulsion in religion"13

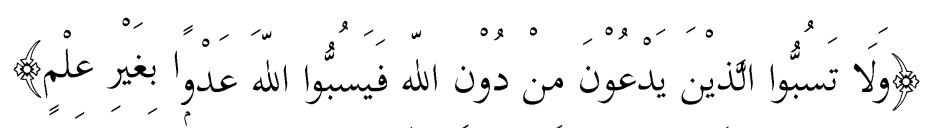

"Revile not ye those whom they call upon besides God lest they out of spite revile God in their ignorance". ${ }^{14}$

Islam not only lays stress to have faith what has been revealed on Holy Prophet (SAW) but also teaches to follow the teachings of all Holy Prophets right from Hazrat Adam till Hazrat Issa (Jesus). Quran says:

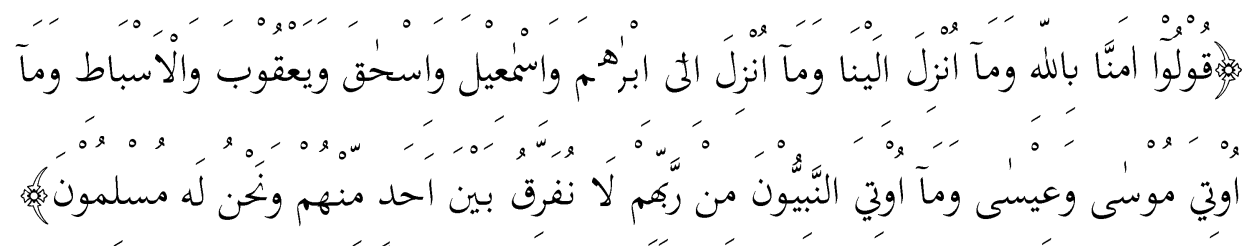

Say ye: "We believe in God and the revelation given to us and to Abraham, Isma il, Isaac, Jacob and the Tribes and that given to Moses and Jesus and that given to (all) Prophets from their Lord we make no difference between one and another of them and we bow to God (in Islam)., 15

This verse, on one hand clearly negates the concept of differentiation among all Holy Prophets but also promotes equality and respect for

${ }^{13}$ Al-Qurān 2:256

${ }^{14}$ Al-Qurān 6: 108

${ }^{15}$ Al-Qurān 2:136 
Religious Tolerance - A Tool for Interfaith Harmony in Pakistan

different faiths on the other hand. Again Quran says:

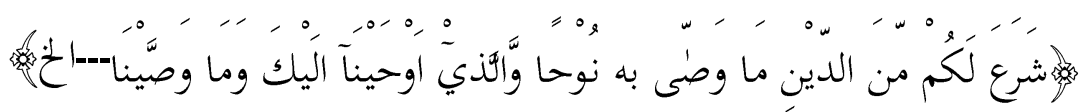

"The same religion has He established for you as that which He enjoined on Noah-The We have sent by inspiration to thee-And that which We enjoined". ${ }^{16}$

Then Quran Says:

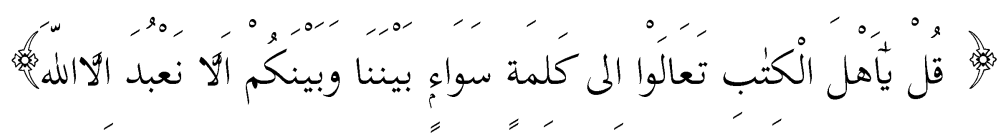

Say: "O people of the Book! Come to common terms as between us and you: that we worship none but God."

Indubitably, all the divine religions believe upon oneness of God and emphasize upon the oneness of God. The Sovereign power is same i.e. God who is the Sustainer and Creator. Quran says:

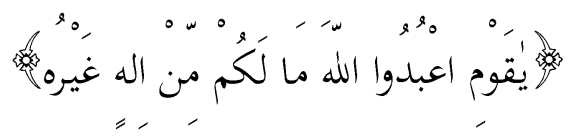

"O my people! worship God! ye have no other god but Him." 18

Every messenger of God preached the same. The Holy Quran says about Hazrat Moosa (Moses):

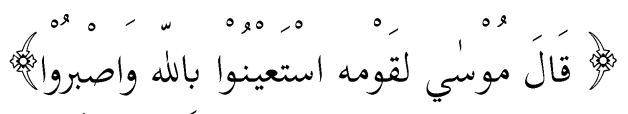

"Said Moses to his people: "Pray for help from God and (wait) in patience and constancy."19

And about Hazrat 'Īsā (Jesus Christ):

\footnotetext{
${ }^{16}$ Al-Qurān 42:13

${ }^{17}$ Al-Qurān 3:64

${ }^{18}$ Al-Qurān 7:59

${ }^{19} \mathrm{Al}-$ Qurān 7:128
} 
Religious Tolerance - A Tool for Interfaith Harmony in Pakistan

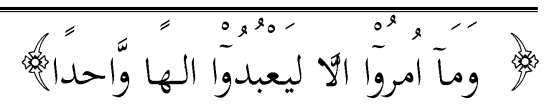

"Yet they were commanded to worship but one God.",20

And again Holy Quran narrates:

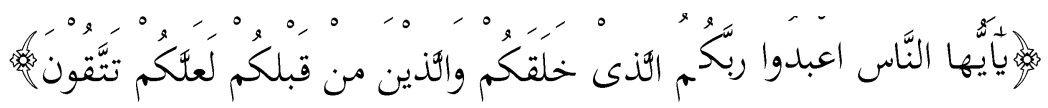

"O ye people! Adore your Guardian-Lord who created you and those who came before you that ye may have the chance to learn righteousness. ${ }^{21}$

\section{RESPECT FOR RELIGIONS AND RESPECT FOR HUMANITY IN THE LIGHT OF OTHER SCRIPTURES:}

Prime consideration and colossal stimuli for interfaith harmony is the requirement of respect of humanity and religion in the light of Old and New Testament which is common among all the religions and all the Divine Books testify it, especially Islam takes the prime place to propagate such a sublime cause. The Prophet of Islam introduced this noble concept in Arab peninsula to nurture an exceptional civilization wherein the noble notion of "Humanity is first" pervaded and prevailed in the society. During conquest of Makkah (Mecca) Holy Prophet of Islam propagated the concept of harmony in similar fashion.

There are some golden quotes of Hazrat Ibrahim (Abraham) in Old Testament which emphasis upon the need of compassion and sympathy among the human beings, societal empathy and tolerance etc. Holy Book of Jews "Talmudiminon" states:

“To feed hungry, dress up the one who doesn't have the clothes, to speak

\footnotetext{
${ }^{20}$ Al-Qurān 9:31

${ }^{21}$ Al-Qurān 2:21
} 


\section{Religious Tolerance - A Tool for Interfaith Harmony in Pakistan}

politely with the misery-stricken, advance justice among humans and remain grateful to the immortal God". 22

Similarly, Talmudminon states the sayings of revered religious scholars of Jews who stressed upon the elements of equality and equity among human fraternity, enlightenment, compassion and tolerance as:

"Man peeps into the lives of neighbors (others) to highlight their faults, be it pretty tiny and forgets to look into one's own huge moral defects. Small place is sufficient so for as love is concerned but huge space in insufficient where the hatred permeates". ${ }^{23}$

Historically, the followers of Judaism avoid to live in coexistence with the followers of other religions and nations and show intolerance in this regard but the real teachings of their scholars propagate the concept of harmony, tolerance and sympathy among human-beings. "Everyone should, with humility and tolerance, coexist with other human beings and one's own religion". ${ }^{24}$ While teaching one of their disciple said: "Do justice generously, think with purity and love your neighbor". ${ }^{25}$

Contrary to Talmud's teachings, Jews believed upon the bigoted concept that they are different from other races and people, they are unique on planet earth and the rest of the race are supposed to serve them because God doesn't like non-Jews people. This bigotry became national pride of Jews with the passage of time.

Following teachings are enumerated so for as the killing of an innocen

${ }^{22} \mathrm{H}$ Polano, Talmud, Urdu trans. Stephan Bashir (Gujranwala: Maktaba Anaweem, 2003), 141.

${ }^{23}$ Talmud, 103-189

${ }^{24}$ Ibid., 162

${ }^{25}$ Ibid., 141 
t person or Qisas (Revenge/Badla) is concerned while implementing these teachings and principles, an ideal society can be formed.

"Neither sons should be killed in lieu of their father's illegal act, nor fathers should be killed for their sons' illegal acts, one should be killed for one's illegal act/sin". ${ }^{26}$

Harazt 'Îsā (Jesus Christ) was such a noble soul who united the people, produced among hearts, curbed the hatred among human beings and propagated love. Hazrat 'İsā promoted harmony, love, tolerance and advised to hate intolerance in these words:

"Do not highlight the faults of others so that your faults may not be highlighted, weigh the way you want others to weigh yourself by using same scales". 27

The only important point in Hazrat 'Îsā's teachings was to build noble character and spread peace, love and tolerance:

"The most salient feature of Christianity were fraternity, equality and tolerance which became the basis of participation of many smaller sects and factions of Greece and Rome races in Christian Movement due to their deprivations in material worldly amenities and due to universal message of love, compassion and harmon". ${ }^{28}$

Hazrat 'Îsā believed in resolving the disputes among people, build peace and love to maintain a peaceful universal society.

"When masses will taunt, tease and abuse you, every bad thing will be

${ }^{26}$ Kitab-e-Muqaddas, Istisna'a, chapter 15, verse 1, 2 (Lahore: Bible Society, 2001).

${ }^{27}$ Kitab-e-Muqaddas, Mataa, chapter 7, verse 12 (Lahore: Bible Society, 2001).

${ }^{28}$ Mazhar ul Din Siddiqui, Mazahib-e-Alam (Lahore: Idara Siqafat-e-Islamiya, 1956), 150. 
The Scholar Islamic Academic Research Journal

Vol. 7, No. 1 || January -June 2021 || P. 52-79

https://doi.org/10.29370/siarj/issue12ar4

attributed to you but you will still commend them instead reciprocating the same". 29

Hazrat 'Isāa advised not to speak ill to one who does the same instead maintain an environment of peace, love and compassion.

"Do not combat a miscreant rather if one slaps you on right cheek, offer your left cheek, if one takes your shirt forcefully, offer him your robe". ${ }^{30}$

Hazrat 'Isā while advising the humanity state that this is an act of piousness to expect favour in return of favour.

"This is not commendable if you return love to the people who love you because even sinner and miscreants love the one who love them". 31

Christianity forbids to possess sword during any feud even in self defence which factum is clear from the teaching of Hazrat 'I $\bar{s} \bar{a}$. When officials came to apprehend Hazrat 'Îsā then instead lifting some weapons $\mathrm{He}$ (Hazrat 'Isā) allowed them to do that to their utmost satisfaction.

“There isn't any good fruitful tree which produces bad fruit neither there is not any bad tree which bring good fruit. Good human being procures nicest things from inside his heart. When you don't act good as per my advice, then why do you call me the Cherisher, Sustainer". 32 "O, people of planet earth, raise slogan of ecstasy before Almighty God and merrily pray before him". 33

Again it is narrated in another place. "O, who do justice on earth, fear God

\footnotetext{
${ }^{29}$ Kitab-e-Muqaddas, Mataa, chapter 5, verse 9.

${ }^{30}$ Ibid., chapter 5 , verse 5.

${ }^{31}$ Kitab-e-Muqaddas, Luqa, chapter 6, verse 32.

${ }^{32}$ Ibid., chapter 6, verse 44-46.

${ }^{33}$ Kitab-e-Muqaddas, New and Old Ehadnama (Zabur) chapter 100, verse 1-2 (Lahore: Bible Society, 2001).
} 
The Scholar Islamic Academic Research Journal

Vol. 7, No. 1 || January -June 2021 || P. 52-79

https://doi.org/10.29370/siarj/issue12ar4

and pray". 34

In Old Testament it is stated:

"Israelites stayed anchored where they were present and they spent one fourth part of the day while reciting Divine Book. Fatiha said that stand up and praise thy immortal lord". 35

"O lord save us from his hand, so that everyone could be aware that You (God) is all alone and all powerful". 36

In New Testament is stated:

"Blessings are different but soul is one, services are different but God is One and $\mathrm{He}(\mathrm{God})$ is the One who produces and provides differently". 37

All the faiths look aligned as for as the concept of respect and harmony for humanity is concerned. In Old Testament what Hazrat Ibrahim (Abraham) said is also narrated in Holy Book of Jews i.e., Talmud.

"Man keeps an eye on tiny acts of one's neighbor but forgets to take stock of one's own defects. Love and compassion need small place but huge space is insufficient for hatred. Sacrifice for others as their wish so that they could reciprocate the same for you. A person is an idiot who deprives someone from shadow". ${ }^{38}$ The religious stalwarts of Judaism preach in similar fashion:

"To alienate or separate people from each other is not the purpose of

\footnotetext{
${ }^{34}$ Kitab-e-Muqaddas, New and Old Ehadnama (Zabur) chapter 2, verse 11.

${ }^{35}$ Kitab-e-Muqaddas, New and Old Ehadnama (Taurat) chapter 9, verse 2-7.

${ }^{36}$ Kitab-e-Muqaddas, New and Old Ehadnama (Yusayah) chapter 37, verse 20.

${ }^{37}$ Kitab-e-Muqaddas, New and Old Ehadnama (Karanthyun) chapter 12, verse 45.

${ }^{38}{ }_{1} \mathrm{H}$ Polano, Talmud, Urdu Trns by Stephan Bashir (Gujranwala: Maktaba Anaweem, 2003), 103-189.
} 
The Scholar Islamic Academic Research Journal

Vol. 7, No. 1 || January -June 2021 || P. 52-79

https://doi.org/10.29370/siarj/issue12ar4

Judaism". 39

"Everyone should spend life with humility and compassion, not only with their own faith but with other people". 40

Old Testament focuses upon the respect of humanity in following words:

"Do not act cruel with your deprived and misery-stricken slave even he is your brother or those who are away from their homes and live at your territories". 41

This aspect also crystal clears that how teachings of Judaism are peace and interfaith harmony-oriented:

"When you advance towards some city for a war, send the message of peace, accord and resolution first". ${ }^{42}$

"Curse upon one who kills an innocent person for reward and people say aameen". 43

Dr. Shibli has copied with respect to New Testament that:

"Love your enemies, meet with eyes having love in them, do mercy upon ones who keep grudges, treat them well who do bad and hate with you". 44 Afore-referred teachings of Judaism tell that the whole teachings revolve around the basic concepts of love, compassion, respect for humanity and respect for the followers of other faiths. This can greatly to create an atmosphere of peace, love and harmony and also develop the atmosphere of unity among faiths, which could help eliminate the clash of faiths and

\footnotetext{
${ }^{39}$ Ibid. 141.

${ }^{40}$ Ibid. 162.

${ }^{41}$ Kitab-e-Muqaddas, Istisna'a, chapter 14, verse 24.

${ }^{42}$ Ibid., chapter 10, verse 20.

${ }^{43}$ Ibid., chapter 25, verse 27.

${ }^{44}$ Dr Ahmed Shibli, Muqarna-tul-adyaan-ul-masihyah (Egypt: Mataba-tun-nahzah al-misriyyah, 1960), 33.
} 
civilizations.

It is manifestly clear from all the Divine Books that God is one and He is the sustainer, provider, omniscient, problem-solver and all-powerful. All the faiths are in accord as for as the oneness of God is concerned and this fact also impliedly enshrines the concept of love for humanity and other faiths and that is why the concept of inter-faith harmony is flourishing among the people of different faiths.

Islam is a faith of peace and tolerance and it preaches the same. Islam, not only advises it's followers to keep and uphold peace among each other rather conveys the same message to everyone.

Allah Almighty states:

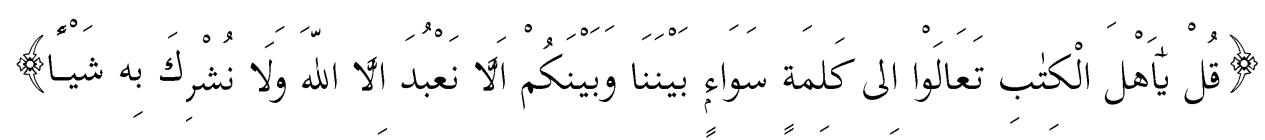

Say: "O people of the Book! Come to common terms as between us and you: that we worship none but God". 45

Due to this clear and manifest motto of Islam, all the people of different faiths came under this rubric. This was the reason that anyone who lives within an Islamic state is free to practice one's religious practices, live peacefully and as per one's terms. In an Islamic State, the entire religious worship place was habilitated by the followers, be it temple, church or synagogue etc.

\section{INTERFAITH HARMONY IN PAKISTANI CONTEXT:}

Although Pakistan got independence on the name of Islam but minorities had also participated into the movement of independence and later on its

\footnotetext{
${ }^{45}$ Al-Qurān 3:64
} 
The Scholar Islamic Academic Research Journal

Vol. 7, No. 1 || January -June 2021 || P. 52-79

https://doi.org/10.29370/siarj/issue12ar4

development. The following table shows the magnitude of minorities in Pakistan.

POPULATION BY RELIGION -TABLE $1^{46}$

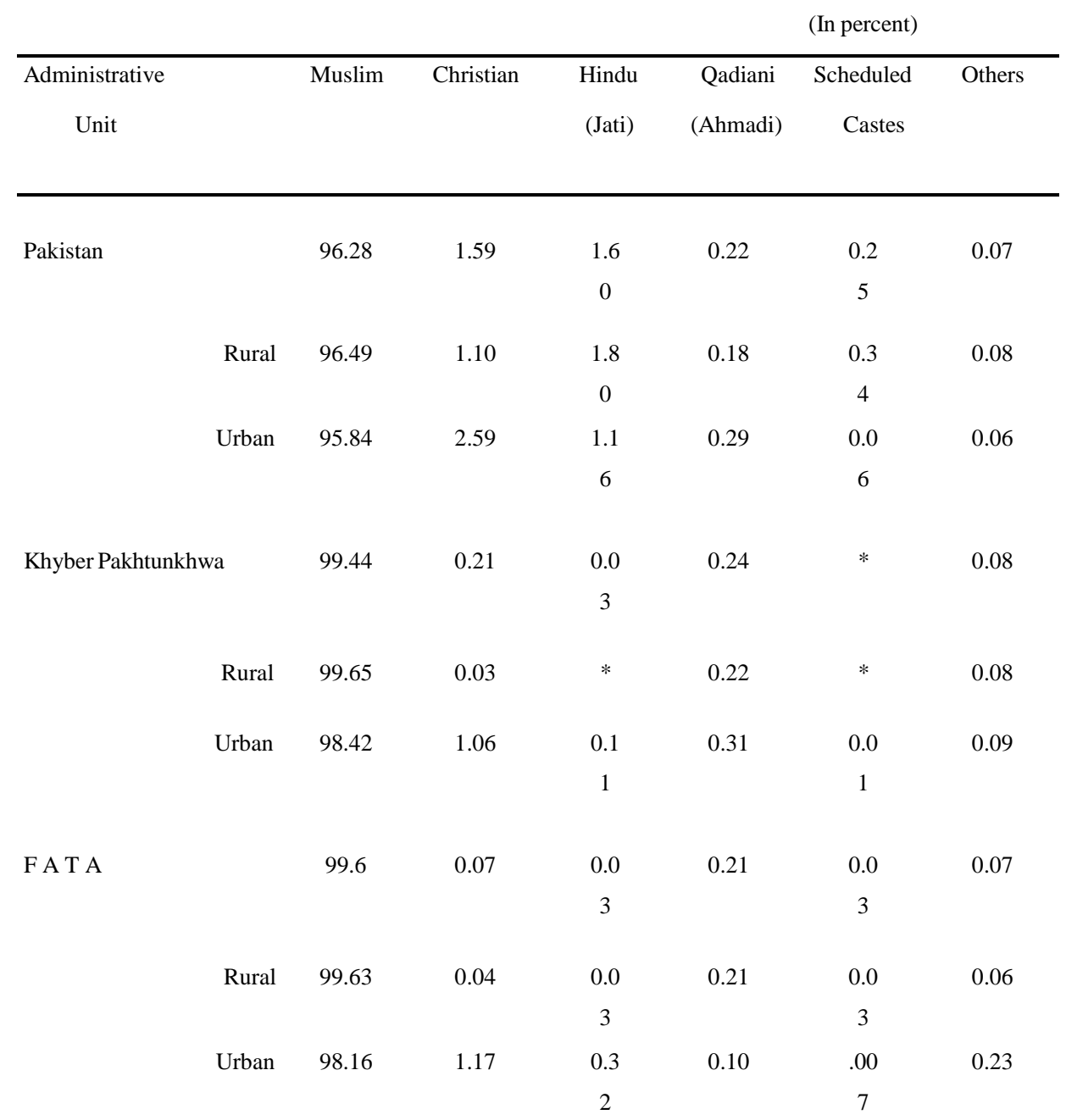

\footnotetext{
${ }^{46}$ Pakistan Bureau of Statistics Government of Pakistan, available on https://www.pbs.gov.pk/sites/default/files//tables/POPULATION\%20BY\%20RE LIGION.pdf
} 


\begin{tabular}{|c|c|c|c|c|c|c|c|}
\hline \multirow[t]{2}{*}{ Punjab } & & 97.21 & 2.31 & 0.1 & 0.25 & 0.0 & 0.07 \\
\hline & & & & 3 & & 3 & \\
\hline & Rural & 97.66 & 1.87 & 0.1 & 0.19 & 0.0 & 0.08 \\
\hline & & & & 5 & & 5 & \\
\hline & Urban & 96.25 & 3.27 & 0.0 & 0.37 & 0.0 & 0.03 \\
\hline & & & & 6 & & 2 & \\
\hline \multirow[t]{6}{*}{ Sindh } & & 91.31 & 0.97 & 6.5 & 0.14 & 0.9 & 0.08 \\
\hline & & & & 1 & & 9 & \\
\hline & Rural & 88.12 & 0.14 & 9.7 & 0.12 & 1.7 & 0.06 \\
\hline & & & & 7 & & 9 & \\
\hline & Urban & 94.67 & 1.84 & 3.0 & 0.17 & 0.1 & 0.10 \\
\hline & & & & 8 & & 4 & \\
\hline \multirow[t]{6}{*}{ Balochistan } & & 98.75 & 0.40 & 0.4 & 0.15 & 0.1 & 0.10 \\
\hline & & & & 9 & & 0 & \\
\hline & Rural & 99.42 & 0.06 & 0.1 & 0.14 & 0.1 & 0.10 \\
\hline & & & & 5 & & 2 & \\
\hline & Urban & 96.61 & 1.49 & 1.5 & 0.16 & 0.0 & 0.10 \\
\hline & & & & 8 & & 5 & \\
\hline \multirow[t]{5}{*}{ Islamabad } & & 95.53 & 4.07 & 0.0 & 0.34 & $*$ & 0.03 \\
\hline & & & & 2 & & & \\
\hline & Rural & 98.80 & 0.94 & $*$ & 0.23 & $*$ & 0.03 \\
\hline & Urban & 93.83 & 5.70 & 0.0 & 0.40 & $*$ & 0.03 \\
\hline & & & & 3 & & & \\
\hline
\end{tabular}

* Refers to a very small proportion.

People and institutions do follow the same teachings, which they inherited.

All the institutions of this homeland played their role with respect to interfaith harmony and became an example before all the world by being playing their vital role are serving their homeland and are providing a safe, peaceful and compassionate environment to its citizens and without discriminating anyone with any faith, cult or creed. 
The Constitution of Pakistan guarantees the safety of life, honor and property of every citizen, be it Muslim or Non-muslim. It is enshrined in the Constitution: "The social and religious rights of minorities will be safeguarded". 47

The Constitution of Pakistan ensures and provides the guarantee for the protection of the economic, social and religious rights of all Pakistani citizen without any discrimination of being a Muslim or Non-Muslim. The essence is provided in following words.

- All citizen of Pakistan will be equal before law. ${ }^{48}$

- Without any discrimination Muslim and Non-Muslim can reside anywhere within Pakistan. ${ }^{49}$

- There will be complete freedom of expression. ${ }^{50}$

- Everyone is free to choose any trade or profession. ${ }^{51}$

- There will be a respect and protection of culture and language of any citizen of Pakistan. ${ }^{52}$

\section{SERVICES OF NON-MUSLIMS IN PARLIAMENT OF PAKISTAN:}

Not only in social and public domains, all the Non-Muslims are serving in all the pivotal state institutions and even their participation in political spheres is worthwhile. Ever since the end of British rule in Sub-Continent and their departure, the Non-Muslims residing here started serving Pakistan. Even Non-Muslims enthusiastically participated in all the freedom movements for their homeland and not for their religious

\footnotetext{
${ }^{47}$ Tarikh Ain-e-Pakistan 1909-1973, 82.

${ }^{48}$ The Constitution of the Islamic Republic of Pakistan, 1973, Art 25.

${ }^{49}$ Ibid., Art 15

${ }^{50}$ Ibid., Art 19

${ }^{51}$ Ibid., Art 18

${ }^{52}$ Ibid., Art 28
} 
freedom. During initial days of British rule, Hindus, Sikhs, Christians, Buddhist, Parsi's have started serving this homeland in different capacities. $^{53}$

Having a cursory glance on the role and services of Non-Muslims, the name of Dada Bhai Noru Ji comes at fore when in 1885 became the member of Bombay Legislative Assembly and He was the first Paarsi who became the member of British House of Commerce. ${ }^{54}$ Similarly many Hindu members of Bombay Legislative Assembly i.e., Kaashi Naath, Mehek Talang took the reigns in many crucial meetings.

General Elections of 1945-46 were contested under the slogan of new homeland i.e., Pakistan wherein two major parties of Christian contested the Elections on the name of Pakistan and became member of Punjab Assembly including Headmaster of Rawalpindi Fazal Ilahi, Diwand Bahadur, and SP Singha. ${ }^{55}$ Non-Muslim leadership played its pivotal role when he voted in Pujnab Assembly in the favour of Pakistan and this was why Punjab province was included in Pakistan. ${ }^{56}$

\section{SERVICES OF NON-MUSLIMS IN THE JUDICIARY OF PAKISTAN:}

Many judges of the apex court of Pakistan were the Christians. After the establishment of Pakistan, all the judicial affairs were in their hands, which they performed with huge responsibility and on best lines and as per their oath, which could be the beacon examples for upcoming Pakistani

\footnotetext{
53 Ahmed Saleem, Pakistan main makhloot aur judagana intikhab ki siyasat (Islamabad: Dost publications), 10.

${ }^{54}$ Cowasjee, Ardeshir \& Dadabhai Naoroji, Sindh Quarterly, Vol. xii, no.2,1984, p: 53

${ }^{55}$ Ye Dais Hamara Ha, 133.

${ }^{56}$ Ibid.
} 
The Scholar Islamic Academic Research Journal

Vol. 7, No. 1 || January -June 2021 || P. 52-79

https://doi.org/10.29370/siarj/issue12ar4

generations. Following is a brief narration of those Non-Muslim Judges who played their exceptional role in Pakistan's Judicial System and whose efforts took Pakistani judiciary to a towering height.

This has been hotly debated that whether a Non-Muslim can serve as the Chief of an institution in Pakistan, the answer is yes and there is no such bar given in any law or constitution. Case of Shahid Orakzai explains this fact in following words:

In the Shahid Orakzai Case, the SC in interpreting Article 2 and 2-A ruled that the said articles do not per se prohibit Non-Muslims from being appointed as chief justice of Pakistan. The Court held: “...The petitioner has not been able to show us any bar in any of the Articles of the Constitution, including Articles 2 and 2-A of the Haq Nawaz and Others v. Province of Punjab through Chief Secretary, Lahore, 1997 MLD 299, Shahid Orakzai and Another v. Federation of Pakistan, PLD 2008 SC 77, that a non-Muslim cannot be appointed as Chief Justice or Acting Chief Justice of Pakistan or a Judge of the Supreme Court...The legislature may in its domain subject to the Constitution and the principles of equality before law and equal treatment before law can make a law that a nonMuslim citizen cannot be appointed against a particular post but there is no prohibition in the Constitution or any law that a non-Muslim cannot be appointed as a judge or Chief Justice in the Superior Courts". Certain important personalities are being mentioned here such as Chaudhry Chando Lal Advocate ${ }^{57}$, Chandar Baala Gor, ${ }^{58}$ A.R. Geremy, ${ }^{59}$, A. R.

\footnotetext{
${ }^{57}$ Born on April 16, 1907, in a village on the outskirts of Sheikhupura. He graduated from Murray College in 1921 and did his LLB from Punjab University in 1933 and became the first Christian Advocate in the area. See: Jang Daily, Lahore, Golden Jubilee Special, July 26, 1997.
} 
The Scholar Islamic Academic Research Journal

Vol. 7, No. 1 || January -June 2021 || P. 52-79

https://doi.org/10.29370/siarj/issue12ar4

Gomez $^{60}$ Benod Bahadur Chaudhry. ${ }^{61}$

SERVICES AND ROLE OF NON-MUSLIMS IN THE DEFENCE OF PAKISTAN:

Under Article 245 of the Constitution of Pakistan, armed forces will defend frontiers of Pakistan against foreign aggression and help the civil government, whenever is required under the law and under the directions of federal government. ${ }^{62}$

As per the spirit of this Article there is no discrimination regarding Muslim and Non-Muslim. Pakistani citizenship is the eligibility criteria for getting inducted in armed forces of Pakistan, be it soldier or officer cadre. Oath provided in Third Schedule of Constitution narrates the loyalty and allegiance with Pakistan, which is an act of real democracy and it is not on the basis of any religious or cult affiliation. This aspect also manifestly clears that like the other two pillars of state there is no impediment for Non-Muslims to be part of it. It just requires responsibility and discharge

\footnotetext{
${ }^{58} \mathrm{He}$ was born in 1927 in the village of Ola Badi in Faridpur. In 1954, he was elected a member of the East Bengal Legislative Assembly and in 1955, he was elected a member of the Constituent Assembly. See: Pakistan and Minorities, p. 479

${ }^{59} \mathrm{He}$ studied at reputed institutes like Stephen's College, Delhi, For Man Christian College, Lahore and Law College, Lahore. After obtaining a law degree in 1923, he started practicing law in Mardan Bar. He practiced till death in Lahore High Court. See: Pakistan and Minorities, p.460.

${ }^{60}$ Born in 1940, he graduated in 1926 and passed his MA in English in 1928. He was twice a councilor of the Calcutta Corporation and twice a member of the United Bengal Legislative Assembly. He performed the most important feat when he voted for Pakistan on the occasion of Partition of India. See: Pakistan and Minorities, p. 461

${ }^{61}$ Born on April 2, 1904 in Chittagong. In 1931, he obtained a law degree from Calcutta University. See: Pakistan and Minorities, p. 463.

${ }^{62}$ The Constitution of the Islamic Republic of Pakistan, 1973, 245.
} 
The Scholar Islamic Academic Research Journal

Vol. 7, No. 1 || January -June 2021 || P. 52-79

https://doi.org/10.29370/siarj/issue12ar4

of obligation and nothing else which is the true spirit of democracy.

Being citizen of Pakistan is the basic criterion to be a part of armed forces of Pakistan and there is no impediment or discrimination on the basis of race, color, religion or nation. Article 36 of the Constitution of Pakistan enumerates: "State shall ensure that all citizen of Pakistan will be part of armed forces of Pakistan". 63

The names of Group Captain Aric Gordon, Wing Commander Muroon Lezli Middlecoat, Squardon Leader Peter Christi, Flight Lieutenant Cecil Chaudhry and Flight Lieutenant Willian D. Harley are some of glorious examples of the services rendered by the afore-referred officers in Air Forces of Pakistan as for as aerial defence system of Pakistan is concerned.

Apart from extending meritorious services in Air Forces of Pakistan, NonMuslim youth also rendered outstanding services in Pakistan Navy. Father France Nadeem states: “Admiral Mount Gavin, Vice Chief Admiral Jackson, Frank Peter and David Smith while serving in Pak Navy protected naval frontiers of Pakistan".

\section{MEASURES TAKEN BY THE GOVERNMENT OF PAKISTAN FOR INTERFAITH HARMONY: \\ MINISTRY OF RELIGIOUS AFFAIRS: INTERFAITH HARMONY WING:}

Pakistan is an Islamic State and it has taken concrete measures for the welfare of minorities "Interfaith Harmony Wing". Under the "Rules of Business-1973" this Wing has following mandate:- “a) Policy and legislation of interfaith harmony; b) International agreements and

\footnotetext{
${ }^{63}$ Ibid., Art 39.
} 
The Scholar Islamic Academic Research Journal

Vol. 7, No. 1 || January -June 2021 || P. 52-79

https://doi.org/10.29370/siarj/issue12ar4

commitments of all religious communities and implementation thereof; c) Representation of Pakistan at UN Sub Commission on Prevention of Discrimination to Minorities; d) Minorities Welfare Fund; e) National Commission for Minorities and; f) Evacuee Trust Property Board." 64

\section{PROTECTION OF MINORITIES UNDER LAWS - A BRIEF OVERVIEW:}

Pakistan has also taken steps for the protection and promotion of minority rights which are being mentioned as under:-

i. The Constitution of Pakistan 1973 assures fundamental rights to all people regardless of religion, race, caste, colour or creed. Its articles 20, $21,25,26,27,28$, and 36 make available security and equal rights to all people including Minorities of Pakistan without any discrimination;

ii. Article-20 of the Constitution is important to mention here which provides right to every citizen to profess, practice or propagate his/her religion as per their beliefs;

iii. Offences about the religion has been fixed in the "Pakistan Penal Code1860 " in its Chapter XV;

iv. On the demand of the minorities the system of separate electorate for minorities was eliminated in favour of universal adult suffrage;

v. Besides reserved seats in all Provincial Assemblies, there are 10 reserved seats for minorities in National Assembly and 04 in the Senate. ${ }^{65}$

\section{INTERFAITH HARMONY POLICY:}

It is also the duty of "Interfaith Harmony Wing" to develop policy and law regarding "Interfaith Harmony". The draft on "National Interfaith

${ }^{64}$ Government of Pakistan, Ministry of Religious Affairs and Interfaith Harmony Islamabad, Year Book 2019-2020, 15.

${ }^{65}$ Ibid 
The Scholar Islamic Academic Research Journal

Vol. 7, No. 1 || January -June 2021 || P. 52-79

https://doi.org/10.29370/siarj/issue12ar4

Harmony Policy" has been formulated and processed to finalize. The IH Policy will soon be considered to discuss and finalize by newly made "National Commission for Minorities". 66

\section{DISTRICT INTERFAITH HARMONY COMMITTEES:}

The "District Interfaith Harmony Committees" has been constituted under the directions of the government containing members from all religions and presided by a high level Government Official to take speedy steps to resolve any issue at initial stage and work as task force. ${ }^{67}$

\section{WELFARE OF MINORITIES - A BRIEF OVERVIEW:}

The "Minorities Welfare Fund" is functioning in IH Wing to perform "Small Development Schemes" such as the maintenance of the religious places of minorities, monetary help to the deprived sections of minorities $\&$ award of Scholarships to minority's students. For the period of the FY2019-20 funds were provided as under:-

Funds sanctioned for Small Development Schemes ${ }^{68}$

\begin{tabular}{|c|c|c|c|}
\hline $\begin{array}{c}\text { Fin. } \\
\text { Year }\end{array}$ & $\begin{array}{c}\text { Funds } \\
\text { Allocated }\end{array}$ & $\begin{array}{c}\text { Schemes } \\
\text { Sanctioned }\end{array}$ & $\begin{array}{c}\text { Amount Sanctioned in } \\
\text { Million }\end{array}$ \\
\hline $2019-20$ & Rs. 38.5/- M & 28 & Rs. 35.8/- \\
\hline
\end{tabular}

Funds sanctioned for Financial Assistance

\begin{tabular}{|c|c|c|c|}
\hline $\begin{array}{c}\text { Fin. } \\
\text { Year }\end{array}$ & $\begin{array}{c}\text { Funds } \\
\text { Allocated }\end{array}$ & $\begin{array}{c}\text { Persons / } \\
\text { Beneficiaries }\end{array}$ & $\begin{array}{c}\text { Amount Sanctioned in } \\
\text { Million }\end{array}$ \\
\hline $2019-20$ & Rs. 16.5/- M & 4126 & Rs. 15.94/- \\
\hline
\end{tabular}

Funds sanctioned under Minorities Scholarships

\footnotetext{
${ }^{66} \mathrm{Ibid}$

${ }^{67}$ Ibid., 16

${ }^{68}$ Ibid
} 
The Scholar Islamic Academic Research Journal Vol. 7, No. 1 || January -June 2021 || P. 52-79 https://doi.org/10.29370/siarj/issue12ar4

\begin{tabular}{l|c|c|c|}
\hline $\begin{array}{c}\text { Fin. } \\
\text { Year }\end{array}$ & $\begin{array}{c}\text { Funds } \\
\text { Allocated }\end{array}$ & Students & $\begin{array}{c}\text { Amount Sanctioned in } \\
\text { Million }\end{array}$ \\
\hline $\begin{array}{c}\text { Rs. 34.44/- } \\
2019-\end{array}$ & M & 2888 & Rs. 34.40/- \\
20 & & & \\
\hline \\
ESTABLISHMENT OF & NATIONAL & COMMISSION FOR \\
MINORITIES:
\end{tabular}

The "National Commission for Minorities" (NCM) was created in 1990 by Federal Cabinet Decision vide Case No. 194/15/90 and later on reconstituted and notified on 11.05.2020. Its function is to provide suggestions to the Ministry in policy issues and concerning NOCs for sale/purchase/transfer/gift of common properties of minorities. ${ }^{69}$

\section{ACTIVITIES ABOUT RELIGIOUS FESTIVALS OF MINORITIES:}

For the promotion of the religious activities of minorities, this Ministry has declared ten significant religious carnivals of Minorities to be celebrated officially. These include such as "Christmas and Easter for Christians, Holi and Diwali for Hindus, Baisakhi and Birthday of Guru Nanak for Sikhs, Nauroze for Zoroastrian, Eid-e-Ridvan for Baha'i's, Festival of Lights for Buddhist Community and Chelum Jusht for Kalash people." Similarly Minorities Day-19 celebrations were arranged at official level on 29th July, 2019. ${ }^{70}$

Under the above backdrop it is stated that all Divine faiths were sent by God for the betterment of both the lives i.e., worldly life and the life hereafter because there was a vivid potential of deviation of human beings

\footnotetext{
${ }^{69}$ Ministry of Religious Affairs and Interfaith Harmony Islamabad, Year Book 2019-2020, 17.

${ }^{70}$ Ibid., 16
} 
from the path of success and opting the path of difficulties. Angels queried some concerns from God when the Adam was being created by the God but God refuted these concerns by saying that I am well aware of their all aspects i.e., nuisance or reformation of conduct etc. All religions of the world have staunch faith on Oneness of God along with formation of a peaceful society. They have some differences but there is a need to move in accord so that the main Divine message remains continued from age to age. The hatred, which is being spread on the name of religion is completely away from the real teachings of their own religion. This is due to the ignorance or ulterior motives where powerful exploit the weak and color it with religion to deviate the focus of other people from real purpose.

The best kind of interreligious understanding finds wisdom in four methods such as; by studying deeply into the faiths of others; one's own faith; by going deeper into understanding the common good and; deeper into relationship with others dedicated to interreligious understanding and engagement. ${ }^{71}$ We want now to add a fifth one that is "religious tolerance". Friendship can, obviously, be of many types and be continued in different methods for example friendship. It is hoped that Jews, Christians and Muslims, who worship the Creator and Judge of all hitherto find this God and perform their faith so in a different way, but can create friendship considering the common point that is "for the sake of God". Such friendships might also be pronounced as being "for the sake of God's good purposes", which, as Catholic social teaching repetitively upholds,

\footnotetext{
${ }^{71}$ See further David F. Ford, the Future of Christian Theology (Oxford: WileyBlackwell, 2011) Chapter 6.
} 
are related to "the common good". Thus, the third "deeper" is very important nowadays as Jews, Christians and Muslims try in several areas of the globe to distinguish how to speak and act in the public domain. ${ }^{72}$

\section{CONCLUSION AND RECOMMENDATIONS:}

From the above quotations of divine scriptures, it is cleared that the God of all creations is one and $\mathrm{He}$ is the solo creator of this universe. All the religions believe in this common attribute which is the pivotal point on the basis of which they tend to respect each other's religions. There is no doubt that the teachings of all religions are same. However, in present times it seems impossible to combine all these divine religions for the reason that most of the religions cannot be found in its original form, but efforts can be made to bring them closer and an atmosphere of tolerance and harmony can be created. Keeping in view this, we should perceive interfaith harmony as an effort to make the world more vibrant.

In this regard, it is recommended that Pakistani institutions should follow the teachings provided in the Quran and other divine scriptures concerning interfaith harmony. Some recommendations are being made which need to be prioritized to develop this plan more effectively:

i. For the protection from blasphemy of Prophets in the name of freedom of speech, a section of blasphemy should be included in the penal system of all states and in United Nation itself. Further an effective code of conduct must be made for social media in which the sharing of blasphemous posts should be declared prohibited and infringement of it must be dealt under the "Terrorism Act".

ii. As issues related to minorities are exploited by the West to damage the image of Islam and the country. Thus, concrete measures are required to

${ }^{72}$ Ibid. 
The Scholar Islamic Academic Research Journal

Vol. 7, No. 1 || January -June 2021 || P. 52-79

https://doi.org/10.29370/siarj/issue12ar4

be taken for ensuring the lives and freedom of minorities in Pakistan. By doing this, propaganda against Islam and Pakistan can be curtailed.

iii. Nowadays the usage of social media is on top so through it we can restore the peace in society and can create an environment full of interfaith harmony. On the other hand, to discourage mobster element, there is need to make the laws more effective.

iv. Minorities have played great role in the development of Pakistan. Their worships places are the heritage of its history, the protection of which is the duty of the state. Although the government has developed "Evacuee Trust Property Board" (ETPB) for this purpose but it requires to be activated.

\section{(1) ()(}

BY NC SA This work is licensed under a Creative Commons

Attribution-NonCommercial-ShareAlike 4.0 International (CC BY-NC-SA 4.0) 